\title{
Religious Persecution, Migrations and Practices in Faith-Based Organizations: Some Recommendations from a Qualitative Study
}

\author{
Lucia Boccacin and Linda Lombi
}

\section{$1 \quad$ Introduction}

The chapter focuses on the findings from a qualitative empirical study into the degree of visibility of the religious dimension in hospitality offered to migrants by Faith Based Organizations (from now on FBOs) operating in Italy. ${ }^{1}$

The departure point of this reflection is the relationship between belonging to a FBOs and the public thematization of the religious dimension. This relationship is characterized in contemporary society by a strong ambivalence. In fact, believing without belonging appears be the motto connoting the individualized religious experience of Western society today (Terenzi, 2010: xvii), an experience where religion remains limited to an intimate, psychological and emotional dimension, lodged to a much lesser extent in the social and rational dimensions (see also Chapter 3 ).

On the other hand, the opposite phenomenon is also present in contemporary postmodernity, and may be expressed as belonging without believing. It allows a "rediscovery of the traditional majority religion as a symbol of cultural identity" (Ambrosini, 2014: 1) in the West, and permits the identification of religious symbols as an expression of Western culture, even from people and social components who do not declare a belief or an explicit religious practice. Religion thus becomes a way to give form to a cultural tradition that it is felt should be defended.

This ambivalence does not lack an almost fanatical tendency to reconfigure the social and political structures through a kind of re-sacralization of social ties, offering dramatic examples of fundamentalism.

Under the sociological profile, therefore, the wide and articulated debate on the role of religion in contemporary society (see among others Colozzi, 1999;

1 The chapter is the result of a joint investigation between the two authors. Lucia Boccacin was responsible for paragraphs 1, 5 and 6, and Linda Lombi for paragraphs 2, 3 and 4. Sincere gratitude is expressed to Sara Nanetti for her operative support in the analysis of the empirical material. 
Casanova, 2000; Kurtz, 2000; Bass and Pfau-Effinger; 2012 and the famous dialogue between Habermas and Ratzinger, 2005) tends to indicate, particularly in Western societies, a focus on the religious dimension which, however, demonstrates signs of ambiguity and a marked imbalance against an individualistic drift in which membership in associations and communities tends to become evanescent and irrelevant to the religious experience.

It is in this context that the issue of religious freedom becomes a theme, both for the individual, in particular in the case of forced migration, and for associations and their ability to act in the public space, according to the social citizenship view. $^{2}$

However, which kind of public space for associative membership does exist in today's social contexts, where the fragmentation of the subject reflects dramatically on their relationships?

According to relational theory (Donati, 1991, 2011), it is within the relationships themselves that the possibility must be found to legitimize both the personal religiosity and, in support of the former, the associative experience in the public space. All this in a perspective that understands the distinction between immanence and transcendence, not as antithetical or with a predominance of one over the other, but as the search for interconnection between the two dimensions. Overcoming contrapositive visions allows us to observe how the religious dimension affects the social sphere in people's lives and communities.

The theme of the relationship between associational membership and the religious dimension is at the intersection between the sphere of civil society and that of value orientations, assuming that social ties dictated by membership association produce social integration ${ }^{3}$ and, at the same time, transcendent values of religion, made accessible in everyday life, attribute that intersubjective and social sense and meaning to personal life, which alone are able to constitute the fertilizing substance of integration processes.

In this perspective, there are significant similarities with the concept of common good presented in Chapter 2 with particular reference to the specific role that Fвоs may play, through the interpersonal relationships and social memberships that these involve, ${ }^{4}$ so that "an active tolerance and promotion of fundamental human values" (Donati, 2010:102-103) based on individual and intersubjective religious freedom can be pursued. Hand in hand with this concept of religious freedom is that of a secularism understood as a value

2 On religious freedom and citizenship at the micro level, see Chapter 2; on the issue of social citizenship, see Donati 2000.

3 The relationship between the religious dimension and integration in the international literature is discussed in Chapter 13 .

4 On the concept of the common good, see also: Archer, Donati, 2012. 
originating from the recognition of a common world and combining diverse cultural and ethnic groups as an expression of human society (Donati, 2008a).

Through their actions among their members, but also the recipients and the surrounding social context in general, FBOs can make a distinctive contribution in promoting civicness (Putnam, 2003) by stimulating political and social empowerment attitudes and the development of relationships based on trust and cooperation within a tolerant and intercultural perspective (Donati, 2013). The latter is based on the acknowledgement of the relationality between cultures, rooted in the principles of fraternity, solidarity and reciprocity. Promoting interculturality means, in other words, recognizing that men and women, although they belong to different ethnic groups and cultures, have more in common than they have differences, a fact which leads to the recognition of the Other as a person with dignity and respect (Meda, 2016).

Research Objectives and Design

The research presented in this chapter aims to make a first and not systematic survey of the complex relationship between forced migration and the religious dimension within the environment of Fво in order to shed light on a theme that has been, to date, the subject of scarce attention. Particular attention will be paid to the forms of persecution and religious discrimination that may have led to the migration choice. This limited thematic relevance is rooted in cultural diversity highlighted in the previous paragraph on the public place of religion in the West, the most common point of arrival for migrants, and other contexts.

The difficulties encountered in general in giving voice to the issue must be underlined at this point, both on the side of leaders of FвOs, and the migrants themselves. The reasons for these difficulties are numerous. Among F Bos there is a consensus to provide services, interventions and practices to anyone in need, regardless of religion and the culture of origin. However, it is this "global offer" that limits, in some aspects, the ability to trace the various root causes of the migration in its distinctive forms, especially if forced, and, in particular, the possibility of pinpointing departures prompted by religious persecution.

In addition to contingent problems such as linguistic barrier, migrants are reluctant to emphasize the religious dimension among the reasons that led to the choice to emigrate because of the fear that this may lead to possible reprisals on family members still in the country of origin. The ability to indicate religious persecution as the reason behind migrations rarely occurred, as it rarely occurred with other motivations too, during the first phases of the 
reception process (on this point see also Chapter 11). It was only later, after having established an interpersonal relationship between the contact person from reception organizations and the migrant, that the migrant admitted the real reason for the departure.

A qualitative approach was applied to the research data. Four case studies were conducted, investigated through the administration of eight semi-structured interviews with representatives of ғвоs who participated of their own free will. The interviews were held between April and June 2017. Interview grid was divided into three main sections:

a) the first section attempts to reconstruct the history and characteristics of the organization (founding and transformations, major assets, any stipulation of partnership, resources, goals, norms and values held); 5

b) the second section investigates the issue of religious persecution, exploring the reference scenario (context analysis of origin, flows, data, religious groups involved, etc.);

c) the third section analyses the intervention strategies put in place by organizations, and the outcomes such as in-field projects, results and good practices.

The interviews were transcribed adverbatim and the content analyzed through a hermeneutic methodological approach structured to fully exploit the information gathered and to propose an exploratory analysis guided by the facts and oriented to an understanding and attribution of sense. Subsequently, on the basis of content, an initial system of flexible categories was outlined which made it possible to build a taxonomy of useful concepts and categories for the construction of a coding grid coherent with the interview texts. This preliminary analysis did not intend to capture aspects of similarity and difference between the interviews. Instead, it was geared to the observation of the distinctive aspects of the texts. Following the formulation of the coding grid, the interviews having a congruent coding were grouped in a single case study. Commencing with the initial eight interviews, four case studies were identified as respectively addressing actions of advocacy and dialogue with public institutions (Observatory on Intolerance and Discrimination against Christians in Europe, Religions for Peace), integration and training services (Sant'Egidio Community in Rome and Milan), reception services and response to needs (Opera San Francesco in Milan), and proposals for interreligious dialogue (Service for Ecumenism and Dialogue of the Archdiocese of Milan and the Italian Hindu

5 The AGIL scheme from Talcott Parsons revised through a relational approach (Parsons, 1951; Donati, 1991, 2011) was applied. 
TABLE 14.1 The empirical reference group: case studies and interviews

\begin{tabular}{|c|c|c|c|}
\hline Case studies & FBOS & Qualification & Identifying code \\
\hline \multirow[t]{8}{*}{ First } & Observatory on & Representative & Interview no. 1 \\
\hline & Intolerance and & & \\
\hline & Discrimination against & & \\
\hline & Christians in Europe & & \\
\hline & (OIDCE), & & \\
\hline & Vienna & & \\
\hline & Religions for Peace & Representative & Interview no. 2 \\
\hline & Rome & & \\
\hline \multirow[t]{4}{*}{ Second } & Sant'Egidio & Voluntary & Interview no. 3 \\
\hline & Community, Rome & $\begin{array}{l}\text { Manager of Agents } \\
\text { for Peace }\end{array}$ & \\
\hline & Sant'Egidio & Language Teacher, & Interview no. 6 \\
\hline & Community, Milan & voluntary & \\
\hline \multirow[t]{5}{*}{ Third } & Opera San Francesco & Contact person & Interview no. 4 \\
\hline & for the Poor (osf), & & \\
\hline & Milan & & \\
\hline & San Francesco for the & Specialized operator & Interview no. 8 \\
\hline & Poor (osf), Milan & & \\
\hline \multirow[t]{6}{*}{ Fourth } & Ecumenism and & Representative & Interview no. 5 \\
\hline & Dialogue Service, & & \\
\hline & Archdiocese of & & \\
\hline & Milan & & \\
\hline & Italian Hindu & Representative & Interview no. 7 \\
\hline & Union - Milan Section & & \\
\hline
\end{tabular}

SOURCE: AUTHORS' PERSONAL ELABORATION

Union). ${ }^{6}$ Table 14.1 summarizes the list of interviews conducted and the allocation to the various case studies.

The analysis of the individual cases, by applying the codification previously carried out, identified co-occurrences among the various thematic areas,

6 The authors would like to thank the participating organisations and their representatives for generously donating their assistance and time, not inconsiderable, to the survey. 
which in turn define the mutual relations between phenomena, concepts and categories. After the registration of co-occurrences, summarizing schemes of the process of analysis and narrative expressions present in the texts were produced. ${ }^{7}$

Through an additional coding phase, the most relevant semantic terms in the text were revealed. A Greimas or semiotic square was constructed, allowing the observation of the elementary structure of signification presented by the various narratives (Greimas, 1974) ${ }^{8}$

The overall results of these analyses will be illustrated here in the following order: §3 provides basic information related to the FBOs involved in the study. $\S 4$ will present the findings with respect to the relationship between religious freedom, identity and the response to needs. The relationship between migration and religious persecution in the reception practices of $\mathrm{FBO}$ is the focus of §5. Lastly, §6 illustrates the findings, with particular reference to the type of common good generated by ғвоs and specificities related to the religious dimension that have emerged.

\section{3}

\section{Case Studies}

The first case study involves two FBOs, the Observatory on Intolerance and Discrimination against Christians in Europe (OIDCE), headquartered in Vienna, and Religions for Peace, based in Rome.

The OIDCE is a non-governmental, non-profit organization engaged in the research and analysis of episodes of intolerance and discrimination against Christians in the European context. The organization produces an annual report aimed at documenting discrimination and religious intolerance against Christians. The discrimination of Christians involves limits in the freedom of conscience and freedom of speech. In some European countries, these limits extend to the freedom to wear religious symbols in the workplace, to pray or to ensure the sexual education of their children according to religious values. Recent reports published by the OIDCE have also noted the presence of numerous occasions of social intolerance towards Christians fueled by a marginal or

7 For reasons of space, this contribution will not present the analysis of co-occurrences detected in the interview materials. If further details are required, please refer to the research report available from the authors of this chapter.

8 The semiotic square enables a definition of the general pattern of the articulations of a semantic category, giving form to the sense within a micro-universe of meaning, one composed of the content of the analysed texts. 
stereotypical representation of Christians during public debates proposed by the media.

The association Religions for Peace, also present at the European transnational level, is instead directed more specifically to interdialogue. The aim of this organization is addressed to create a virtuous relationship between interreligious and international groups involving the representative personalities of the various religions. Through an open attentiveness, the diverse religious beliefs attempt to identify those common and universal elements able to promote a compatibility between differences and a lessening of conflict tensions. Supported by this value model, the initiatives promoted by the organization act on several fronts, ranging from the purely religious aimed at dialogue between the different communities to the more sociocultural, which includes multi-religious assistance in hospitals or in prisons. An initiative that in part sums up the values and actions undertaken by the association is the drafting and dissemination of a multi-religious calendar highlighting the festivals of all religions and including citations from different traditions. The willingness to support the interfaith integration process and to contribute to the development of a multi-cultural society is also demonstrated through the promotion of leisure or recreational activities.

Despite the heterogeneous interventions proposed and the different recipients involved, both the OIDCE and Religions for Peace contribute to enhancing the scope of religion within the social context, firstly in a perspective of protection and then promotional. The identification of religiosity as a qualifying component is for the two organizations an ideal reason and value on which to base their actions.

The second case study includes interviews administered to two volunteers of the Community of Sant'Egidio from the centers in Rome and Milan. Among the various services offered by the organization, mention should be made of the canteen, the initiatives for dialogue, appeals and signatures collected for social and humanitarian causes, educational activities and the activities of the Peace Agents. In particular, the Community offers Italian language school services for foreigners. Learning the language can establish a first point of contact in society, aiding the inclusion processes. The classes offered have over time improved in quality and recognition, and now provide a verifiable linguistic certification for the students. The Community's language school is an instrument allowing the full realization of the values woven into the organizations structure, affirming the dignity of every person and establishing personal relationships between operators and migrants.

The volunteers in the Agents of Peace movement offer free services for the elderly connected with the organization. The Italians and foreigners who work 
TABLE 14.2 A summary of the first case study

\begin{tabular}{|c|c|c|c|}
\hline & $\begin{array}{l}\text { OIDCE - } \\
\text { Interview no. } 1\end{array}$ & $\begin{array}{l}\text { Reli } \\
\text { Inte }\end{array}$ & $\begin{array}{l}\text { gions for Peace - } \\
\text { rview no. } 2\end{array}$ \\
\hline \multirow[t]{2}{*}{ History } & & $>$ & $\begin{array}{l}\text { Association founded in } \\
1970 \text { (international } \\
\text { context) }\end{array}$ \\
\hline & & $>$ & $\begin{array}{l}\text { World Assembly in Kyoto } \\
\text { (relationship between } \\
\text { religions as related to } \\
\text { international relations) }\end{array}$ \\
\hline
\end{tabular}

Activities 1. Information

$>$ Provide information to institutions regarding episodes of intolerance and discrimination against Christians in Europe

2. Reception

$>$ Support Christians victims of intolerance or discrimination to tell their story

3. Research

$>$ Collect data about vandalism against Christian symbols

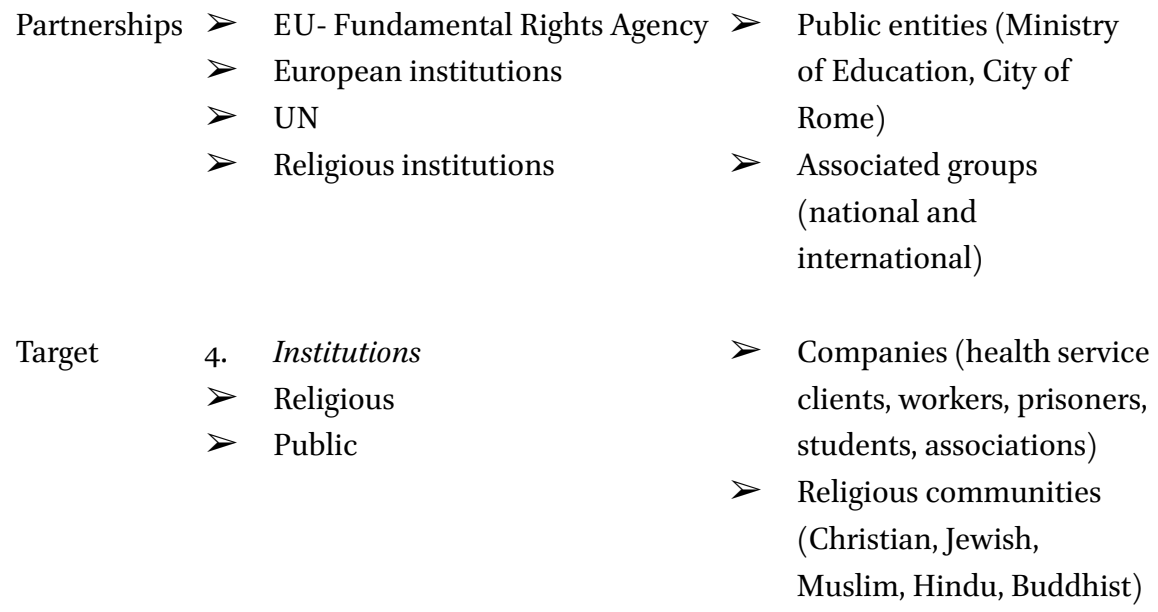


TABLE 14.2 A summary of the first case study (cont.)

\begin{tabular}{|c|c|c|c|c|}
\hline \multirow[b]{2}{*}{ Methods } & \multicolumn{2}{|c|}{$\begin{array}{l}\text { OIDCE - } \\
\text { Interview no. } 1\end{array}$} & \multicolumn{2}{|c|}{$\begin{array}{l}\text { Religions for Peace - } \\
\text { Interview no. } 2\end{array}$} \\
\hline & $\begin{array}{l}> \\
> \\
>\end{array}$ & $\begin{array}{l}\text { Annual reports } \\
\text { Newsletter } \\
\text { Newspaper articles }\end{array}$ & $>$ & $\begin{array}{l}\text { Limited financing } \\
\text { (Calendar, City of Rome) } \\
5 \times 1000 \text { tax donation } \\
\text { receiver }\end{array}$ \\
\hline Scope & $>$ & $\begin{array}{l}\text { Improve institutions' awareness } \\
\text { about appropriate intervention } \\
\text { measures } \\
\text { Improve general awareness about } \\
\text { the situation of fleeing from } \\
\text { persecution and genocide }\end{array}$ & $\begin{array}{l}> \\
> \\
>\end{array}$ & $\begin{array}{l}\text { The relationship between } \\
\text { religion and peace } \\
\text { Preventing tensions and } \\
\text { conflicts } \\
\text { Promoting tolerance } \\
\text { Promoting religious } \\
\text { freedom }\end{array}$ \\
\hline $\begin{array}{l}\text { Norms } \\
\text { Values }\end{array}$ & $>$ & Freedom of religion & $>$ & $\begin{array}{l}\text { Commonalities between } \\
\text { the different religious } \\
\text { traditions (mutual } \\
\text { attention) } \\
\text { Sacred respect of life }\end{array}$ \\
\hline Critical issues & $>$ & $\begin{array}{l}\text { Ill-treatment and discrimination } \\
\text { of Christian refugees and asylum } \\
\text { seekers in some European } \\
\text { countries } \\
\text { Vandalization of churches } \\
\text { Stigmatization of Christians } \\
\text { through the media }\end{array}$ & $>$ & $\begin{array}{l}\text { The relationship between } \\
\text { religion and modernity } \\
\text { Modern individualism } \\
\text { and idealism } \\
\text { Social anxiety caused by } \\
\text { increases in migratory } \\
\text { flows }\end{array}$ \\
\hline $\begin{array}{l}\text { Effects and } \\
\text { best } \\
\text { practices }\end{array}$ & $>$ & $\begin{array}{l}\text { Identification of regular patterns } \\
\text { of discrimination (predictive) } \\
\text { Enunciation of effective } \\
\text { measures to combat discrimina- } \\
\text { tion and intolerance }\end{array}$ & $>$ & $\begin{array}{l}\text { Attention paid to } \\
\text { suffering and to } \\
\text { freedoms } \\
\text { Enhancement of sport as } \\
\text { an alternative to violent } \\
\text { confrontation }\end{array}$ \\
\hline
\end{tabular}

SOURCE: AUTHORS' ELABORATION 
in the movement, in gratitude, return the reception and attention they have received from the Community back to the wider social environment and senior citizens in particular through their volunteer services.

The activities focusing on interreligious dialogue include prayers for peace and participation in a panel of representatives of different religions. The values of humanitarianism, civic, solidarity, hospitality, peace and sharing that guide the work of volunteers within the Community derive from a common religious faith and are transversely promoted in favor of the Other, without distinction of creed. The initiatives are defined according to a predominantly relational register, and in fact the quality of the events is measured through the relationship and mutual confidence established between the participants, allowing a real and symbolic exchange of ideas and values aimed at overcoming ethnicism.

If the process of integration occurs through the relationship created between volunteers and migrants, then in the same way a recognition of the cultural and religious identity of the migrants will require the same relational and personal formula. The Community attempts to establish a genuine reciprocal relationship through the recognition of the person's identity, commencing with being completely open to a person's needs. The religious sphere is the point of reference for the principle values of the organization's activities, and by proactively promoting this openness to all religious identities, their commitment is fulfilled. In this sense, religion is never presented as a reason for division and exclusion, but as an open answer to the needs arising from societies.

During the interview with the Rome volunteer, it emerged that the recipients of Community services included persons who had fled their country of origin because of religious interventions, including in the areas of origin, through. These included Christians from Nigeria, Egypt or Iraq, and also Afghani Shiite Muslims. In responding to the religious persecution reported by migrants, the Community implements specific interventions, including in the areas of origin, through dialogues between religious representatives, appeals and peace initiatives.

The third case study involves interviews with a representative of a reception center and a specialized operator of the Opera San Francesco for the Poor (OSF) in Milan.

The Opera San Francesco for the Poor is a reception center characterized by services that have expanded gradually from the initial canteen to more complex structures dedicated to social integration. This evolution is linked, from an operational point of view, to user requests to meet new and advanced needs prompted largely by the migration flows of the Nineties. The traditional 
TABLE 14.3 A summary of the second case study

\begin{tabular}{lll}
\hline & $\begin{array}{l}\text { Community of Sant'Egidio }- \text { Rome }- \\
\text { Interview no. } 6\end{array}$ & $\begin{array}{l}\text { Community of Sant'Egidio }- \\
\text { Milan }- \text { Interview no. } 4\end{array}$ \\
\hline History & $>\quad$ Active for over 35 years & $>\quad$ Active from 1997 \\
& $>\quad \begin{array}{l}\text { Evolution over time conditioned } \\
\text { by the flow of migrants }\end{array}$ & Evolution from the lower \\
& & $\begin{array}{l}\text { levels of language training } \\
\text { to higher ones (L2-C2) }\end{array}$
\end{tabular}

Activities

1. Education

$>$ Language or vocational training

$>$ Insertion into mainstream education systems

$>$ Relationships with the certifying authorities

2. Social cohesion

$>$ Peace Agents

$>$ Catering services

$>$ Political asylum applications/ appeals

3. Religious identity

$>$ Religious path

$>$ Interventions in prisons

$>$ Aid for religious professions

$>$ Shared prayer periods

$>$ Memorials

$>$ In-class lessons

$>$ Mutual respect for celebrations

4. Combating persecution (the points of departure and destination)

$>$ Dialogue initiatives

$>$ Signature collection

$>$ Peace initiatives

$>$ Prayer in public places
1. Teaching

$>$ Language learning school (Olivetani - Garibaldi)

$>$ Insertion into mainstream education systems

$>$ Language certification exams

2. Social cohesion

$>$ Peace Agents (elderly, cultural initiatives, fundraising through dinners and light meals)

3. Religious identity

$>$ Shared prayers for peace (Assisi)

$>$ Discussion panels (Muslims, Christians)
Partnerships $>$ Religious associations
$>$ Prison
$>$ Caritas
$>$ Evangelical Churches
$>$ Municipality of Rome
$>$ Prefectures

$>$ University for Foreigners Perugia (exams for language certification)

$>$ Refugee camp

$>$ Institute Panagarola

$>$ Schools 


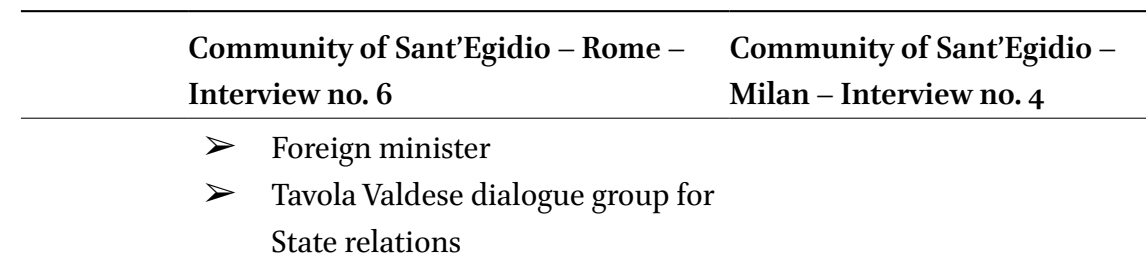

Target

1. Origin

$>$ Romania, Morocco, the Philippines, Georgia

2. Migration due to religious persecution:

$>$ Christians (Nigeria, Egypt, Iraq)

$>$ Afghan Shiite Muslims

Methods $>$ Operator/migrant relationship
1. Origin

$>$ Latin America, Sri Lanka, Eastern Europe, Peru, Ecuador, El Salvador

2. Reason for migration

$>$ Economic, political, defense of values i.e. flee forced abortion

$>$ Free labor from volunteers

$>$ Teacher/migrant personal relationship

$>$ Meetings, prayer, discussion panel

$>$ Social cohesion and interpersonal relationships

$>$ Social justice, help and support for others

$>$ Growth of the sense of belonging to Italy, social and cultural inclusion

$>$ Interfaith dialogue and overcoming of ethnicism

Norms $>$ Free Access Policy (need-based) $>$ Christians, recognition of

Values $>$ Religious, humanitarian, civic

$>$ Solidarity, hospitality, peace, Christ in the poorest sharing dignity, social contact 
TABLE 14.3 A summary of the second case study (cont.)

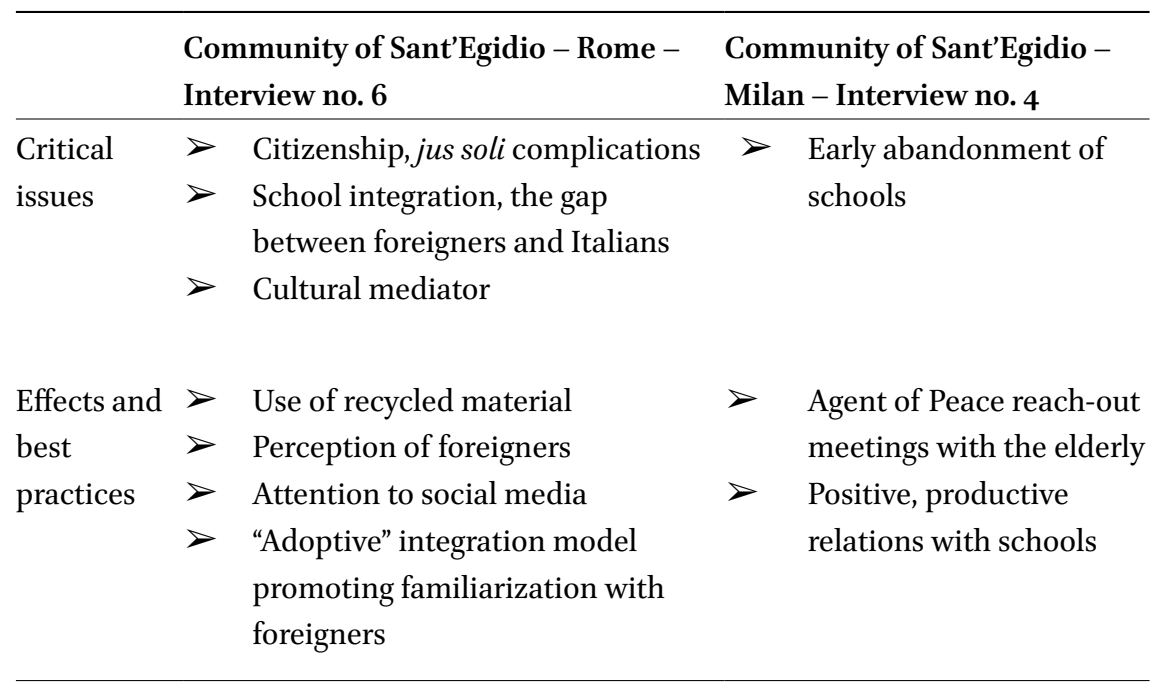

SOURCE: AUTHORS' PERSONAL ELABORATION

recipients of the Opera's works were the homeless. However, the migration phenomenon has resulted in a series of new requirements for assistance, quite different from the previous services. The operators, mostly volunteers, offering service in the centers have diverse professions, including medical doctors, nurses and cultural mediators.

The combination of the religious elements characterizing the Opera as an institution and the respect for other religious and cultural traditions are complementary elements of the service. This respect for different religions, beginning with an absence of pork on canteen menus, coexists with the religious nature of the association. The recognition and respect for different identities is visible, in operational terms, in the quality of the services and the enhancement of the personal dignity of every person.

The ambulatory activities of the Opera San Francesco are addressed to recipients of medical services suffering extremely fragile socio-economic conditions, complicated by psychic fragility and the inability, in some cases, to benefit from the National Health Service. The ability to intercept these problems is ensured by the complete accessibility to the basic services, coordinated by a freely available psychological counselling contact point where decisions are made during the first contact regarding the most suitable cure and treatment path to be undertaken by the specialists in responding to the recipient's needs.

The fourth case study is based on interviews with representatives of two FBOs, the Service for Ecumenism and Dialogue of the Archdiocese of Milan, and the Italian Hindu Union of Milan. 
TABLE 14.4 A summary of the third case study

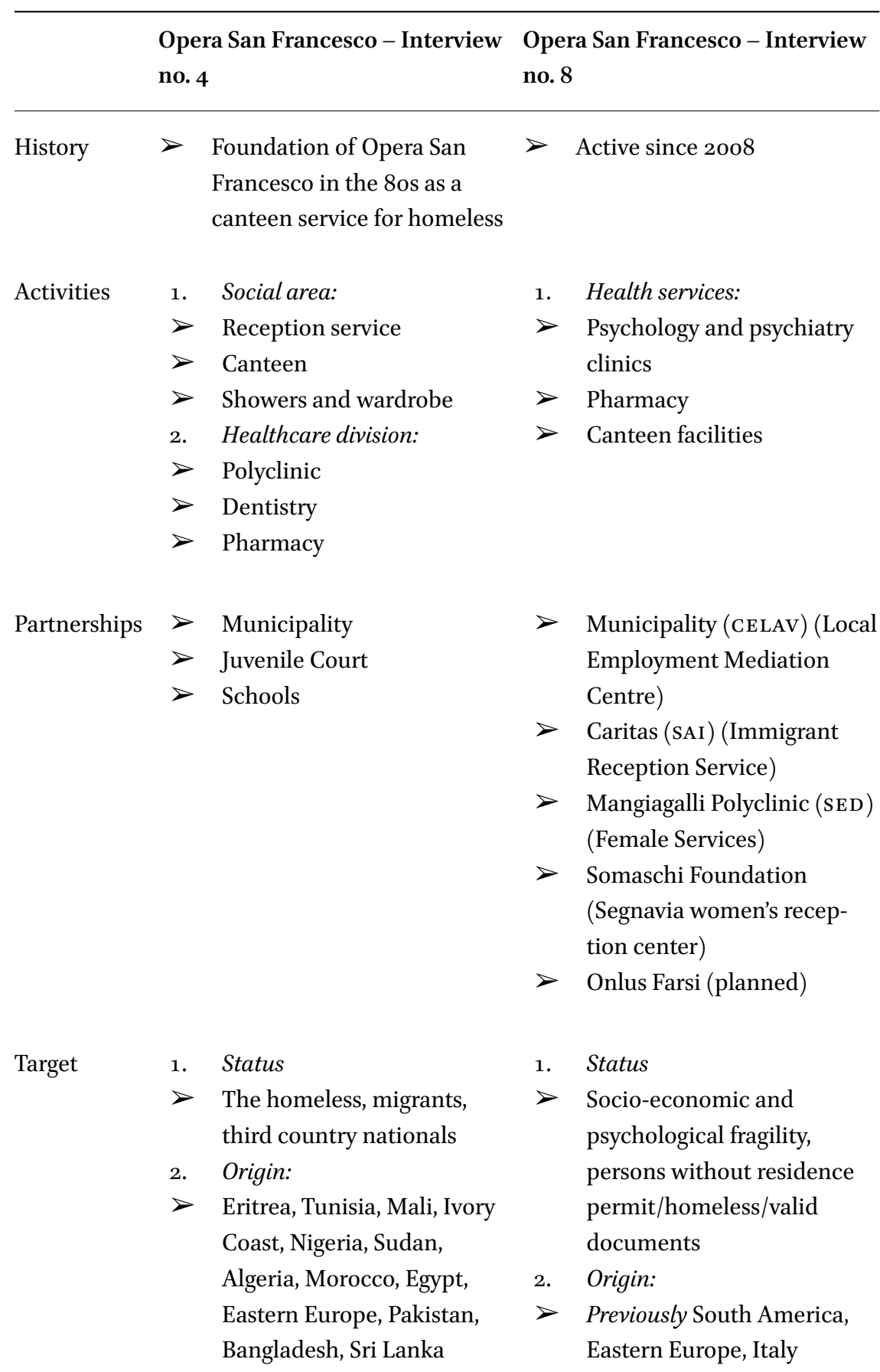


TABLE 14.4 A summary of the third case study (cont.)

\begin{tabular}{|c|c|c|c|c|}
\hline & $\begin{array}{l}\text { Ope } \\
\text { no. } 4\end{array}$ & a San Francesco - Interview & $\begin{array}{l}\text { Oper } \\
\text { no. } 8\end{array}$ & a San Francesco - Interview \\
\hline \multirow[b]{2}{*}{ Methods } & & & $\begin{array}{l}3 \cdot \\
>\end{array}$ & $\begin{array}{l}\text { Currently South America, } \\
\text { Italy, Iran, Pakistan, } \\
\text { Bangladesh, Sri Lanka, North } \\
\text { Africa, China } \\
\text { Migration for religious } \\
\text { persecution: } \\
\text { Somalia, Eritrea, China, } \\
\text { Pakistan, Mauritania, } \\
\text { Bangladesh, Sri Lanka }\end{array}$ \\
\hline & $\begin{array}{l}> \\
> \\
>\end{array}$ & $\begin{array}{l}\text { Interviews in person to } \\
\text { interpret the user's needs } \\
\text { Cards for service access } \\
\text { Increased professionalism in } \\
\text { services } \\
\text { Employees (50) and volun- } \\
\text { teers }(780)\end{array}$ & $\begin{array}{l}> \\
>\end{array}$ & $\begin{array}{l}\text { Psychological counselling } \\
\text { contact point } \\
\text { Personal appointments } \\
\text { Cultural mediation and } \\
\text { teamwork }\end{array}$ \\
\hline Scope & $\begin{array}{l}> \\
> \\
>\end{array}$ & $\begin{array}{l}\text { Integration through the use } \\
\text { of the Italian language } \\
\text { Cultural mediator support } \\
\text { Re-education }\end{array}$ & $>$ & $\begin{array}{l}\text { Personal integration of } \\
\text { recipients into society }\end{array}$ \\
\hline Norms & $>$ & $\begin{array}{l}\text { Registration of recipients } \\
\text { with document } \\
\text { Quality of services and } \\
\text { spaces (canteen, showers) }\end{array}$ & $\begin{array}{l}> \\
>\end{array}$ & $\begin{array}{l}\text { Registration of recipients } \\
\text { Appointment-free access to } \\
\text { services } \\
\text { Free services }\end{array}$ \\
\hline Values & $>$ & $\begin{array}{l}\text { Dignity } \\
\text { Relationality }\end{array}$ & $>$ & $\begin{array}{l}\text { Promotion of human dignity } \\
\text { Meeting between cultures } \\
\text { and religions }\end{array}$ \\
\hline
\end{tabular}




\begin{tabular}{|c|c|c|c|c|}
\hline & $\begin{array}{l}\text { Oper } \\
\text { no. } 4\end{array}$ & a San Francesco - Interview & $\begin{array}{l}\text { Oper } \\
\text { no. } 8\end{array}$ & a San Francesco - Interview \\
\hline Critical issues & $\begin{array}{l}> \\
> \\
>\end{array}$ & $\begin{array}{l}\text { Decreased numbers of } \\
\text { occasional users and increase } \\
\text { in chronic users } \\
\text { Repeat service users } \\
\text { Language problems } \\
\text { Responsibilities towards } \\
\text { minors }\end{array}$ & $>$ & $\begin{array}{l}\text { Problems with waiting times } \\
\text { before social integration } \\
\text { related to political asylum } \\
\text { requests }\end{array}$ \\
\hline $\begin{array}{l}\text { Effects and } \\
\text { best practices }\end{array}$ & $>$ & $\begin{array}{l}\text { Ability to meet the needs } \\
\text { through the evolution of } \\
\text { services } \\
\text { Relationship with external } \\
\text { local services }\end{array}$ & $>$ & $\begin{array}{l}\text { Teamwork involving several } \\
\text { professionals working in } \\
\text { contact with the patient, e.g. } \\
\text { psychologist, physician, } \\
\text { employer, in order to bolster } \\
\text { the recipient's dignity }\end{array}$ \\
\hline
\end{tabular}

SOURCE: AUTHORS' PERSONAL ELABORATION

TABLE 14.5 A summary of the fourth case study

$\begin{array}{ll}\text { Service for Ecumenism and } & \text { Italian Hindu Union (Milan } \\ \text { Dialogue (Archdiocese, Milan) - } & \text { branch) }- \text { Interview no. } 7 \\ \text { Interview no. } 5 & \end{array}$

$\begin{array}{ll}\text { History }>\begin{array}{l}\text { Reorientation of services as a } \\ \text { result of the changes imposed } \\ \text { by migration }\end{array} & \begin{array}{l}\text { Italian Hindu Union founded } \\ \text { in the early nineties }\end{array} \\ & >\quad \begin{array}{l}\text { Religious authority recog- } \\ \text { nized with a Presidential } \\ \end{array} \\ & \begin{array}{l}\text { Decree Law in } 2002 \\ \text { Understanding signed with }\end{array} \\ & \text { the Italian State in } 2012\end{array}$


TABLE 14.5 A summary of the fourth case study (cont.)

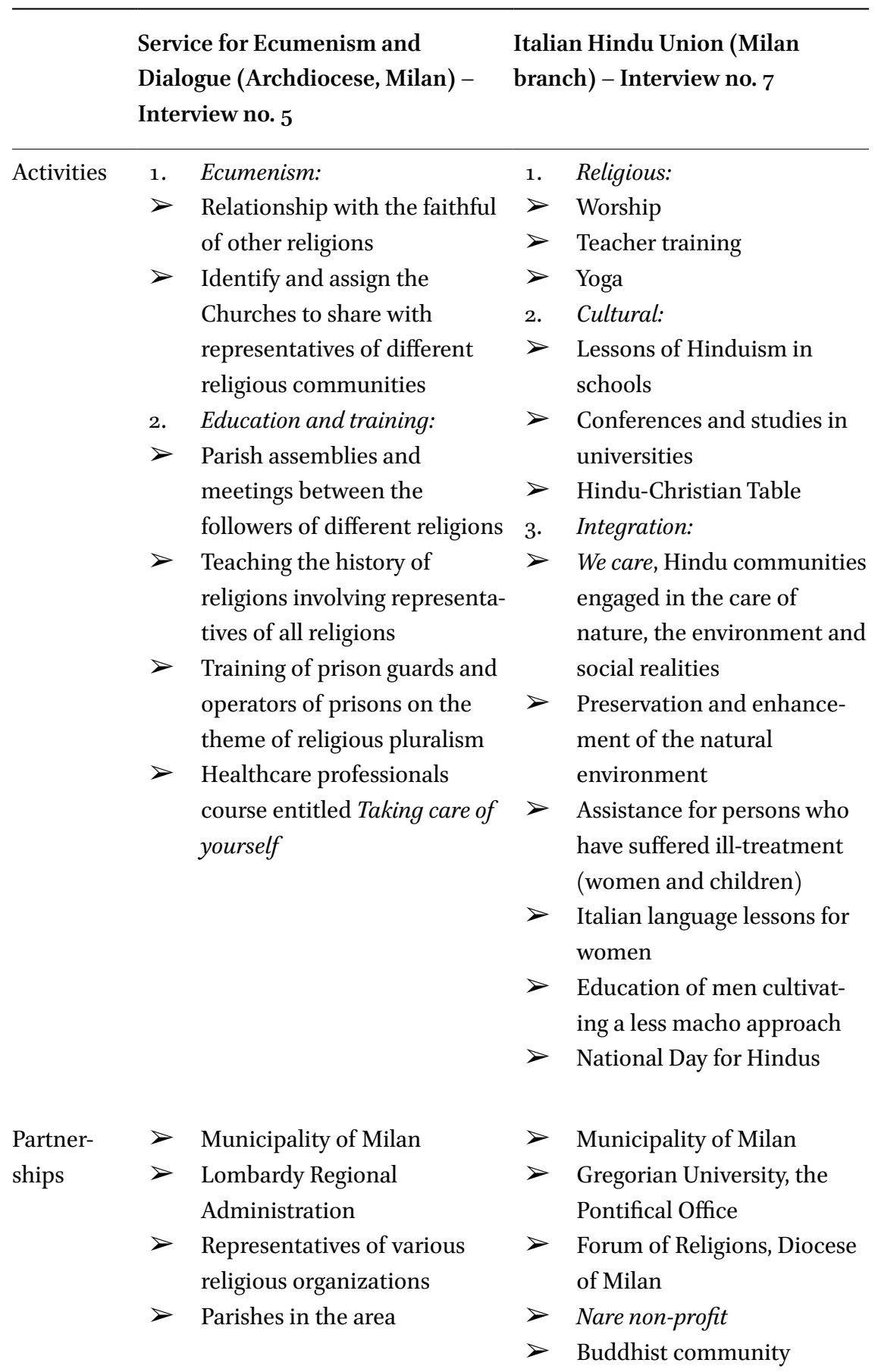




\begin{tabular}{|c|c|c|c|}
\hline & $\begin{array}{l}\text { Serv } \\
\text { Dial } \\
\text { Inte }\end{array}$ & $\begin{array}{l}\text { ce for Ecumenism and } \\
\text { gue (Archdiocese, Milan) - } \\
\text { view no. } 5\end{array}$ & $\begin{array}{l}\text { Italian Hindu Union (Milan } \\
\text { branch) - Interview no. } 7\end{array}$ \\
\hline Target & $\begin{array}{l}2 . \\
>\end{array}$ & $\begin{array}{l}\text { Religious communities: } \\
\text { Orthodox Christians, Sikhs, } \\
\text { Muslims, Jews, Copts, Hindus, } \\
\text { Buddhists } \\
\text { Host communities: } \\
\text { Pastors, pastoral council, the } \\
\text { community of believers }\end{array}$ & 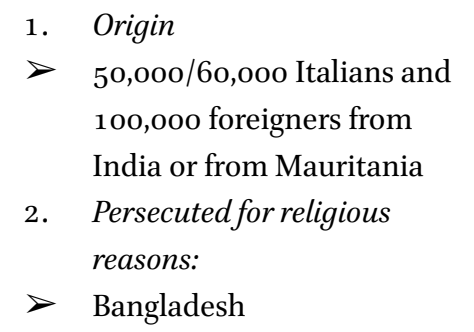 \\
\hline Methods & $\begin{array}{l}> \\
> \\
>\end{array}$ & $\begin{array}{l}\text { Offices responsible for } \\
\text { ecumenism and relations with } \\
\text { Islam, Judaism and other } \\
\text { Eastern religions } \\
\text { Office coordination } \\
\text { Section collaborators } \\
\text { Contact meetings with } \\
\text { political institutions } \\
\text { Research into the potential } \\
\text { needs of the faithful of other } \\
\text { religions } \\
\text { Religious communities }\end{array}$ & $\begin{aligned}> & \text { Self-financing } \\
> & 8 \times 1000 \text { tax donation } \\
& \text { receiver } \\
>\quad & \text { Temple (place of worship } \\
& \text { and assembly) }\end{aligned}$ \\
\hline Scope & $>$ & $\begin{array}{l}\text { Relationship with Christian } \\
\text { Churches, active interreligious } \\
\text { dialogue } \\
\text { Create citizens without } \\
\text { reference to religious } \\
\text { affiliation } \\
\text { Model of distributive interreli- } \\
\text { gious commencing with the } \\
\text { reception } \\
\text { Diversity understood as a } \\
\text { positive contribution to } \\
\text { society } \\
\text { Support in institutional } \\
\text { activities, register of religions, } \\
\text { through the involvement of } \\
\text { religious communities }\end{array}$ & $\begin{array}{l}>\text { Support for the practice of } \\
\text { Hinduism } \\
>\quad \begin{array}{l}\text { Personal integration of } \\
\text { recipients into society }\end{array} \\
>\quad \text { Celebration of religious } \\
\text { ceremonies and weddings } \\
>\quad \begin{array}{l}\text { Promoting knowledge of the } \\
\text { principles of Hinduism }\end{array}\end{array}$ \\
\hline
\end{tabular}


TABLE 14.5 A summary of the fourth case study (cont.)

\begin{tabular}{|c|c|c|c|c|}
\hline & \multicolumn{2}{|c|}{$\begin{array}{l}\text { Service for Ecumenism and } \\
\text { Dialogue (Archdiocese, Milan) - } \\
\text { Interview no. } 5\end{array}$} & \multicolumn{2}{|c|}{$\begin{array}{l}\text { Italian Hindu Union (Milan } \\
\text { branch) - Interview no. } 7\end{array}$} \\
\hline Provisions & & & $>$ & $\begin{array}{l}\text { Free } \\
\text { Assembly of Ministers of } \\
\text { worship }\end{array}$ \\
\hline Values & & $\begin{array}{l}\text { Hospitality } \\
\text { Religious identity }\end{array}$ & $>$ & $\begin{array}{l}\text { The oneness of God } \\
\text { A complete coming together } \\
\text { and unity among the people } \\
\text { under the motto "you and I } \\
\text { are one", non-discrimination } \\
\text { Every living thing, animate } \\
\text { or inanimate, is divine } \\
\text { consciousness } \\
\text { Religion is a way of life } \\
\text { Secularity of the State }\end{array}$ \\
\hline $\begin{array}{l}\text { Critical } \\
\text { issues }\end{array}$ & $>$ & $\begin{array}{l}\text { Tensions between the host } \\
\text { community and other religious } \\
\text { communities } \\
\text { Persecution of those who } \\
\text { convert } \\
\text { Lack of State guarantees for } \\
\text { religious freedom }\end{array}$ & $\begin{array}{l}> \\
>\end{array}$ & $\begin{array}{l}\text { Lack of a national law under } \\
\text { municipal administration on } \\
\text { freedom of religion } \\
\text { Difficulties in opening places } \\
\text { of worship }\end{array}$ \\
\hline $\begin{array}{l}\text { Effects and } \\
\text { best } \\
\text { practices }\end{array}$ & $>$ & $\begin{array}{l}\text { Redevelopment of neighbor- } \\
\text { hoods in a state of disrepair } \\
\text { Overcoming prejudice of } \\
\text { identity and discrimination } \\
\text { Prevention of religious } \\
\text { radicalism }\end{array}$ & $>$ & $\begin{array}{l}\text { Social integration through } \\
\text { reciprocal knowledge } \\
\text { Italy is the only country in } \\
\text { the world where Hinduism is } \\
\text { recognized as a religion }\end{array}$ \\
\hline
\end{tabular}

SOURCE: AUTHORS' PERSONAL ELABORATION

The interview conducted with a manager of the Service for Ecumenism and Dialogue in Milan clearly demonstrates the operational approach of the Church to interreligious dialogue. The organization's activities are based on 
understanding the local religious composition revealed by surveys, as well as the collaboration formulas established between the various religious communities involved in the services for the weak. The purpose of the actions promoted by the Archdiocese is to establish a citizenship that precedes religious affiliation, giving new meaning to both identities and differences. Ecumenism, which characterizes the main intervention ambit, is aimed at fostering relations with the Christian Churches and interreligious dialogue. Among the range of activities supported by the Service for Ecumenism and Dialogue in partnership with the Municipality of Milan are several training initiatives in local elementary schools where the history of religions is presented by members of the various faiths, including Christians, Hindus, Muslims, Buddhists and Jews. The main purpose of this project is to help pupils see religious diversity in terms of an asset, not as a problem.

The second religious body in the third case study is the Italian Hindu Union representing Hindus in Italy. The association was formed in Italy by devotees of Hindu traditions who over time have established a stable center for the State-recognized religion. The main purpose of this ғвоs is the promotion of integration processes between cultures and of initiatives to spread both historical and theological knowledge of Hinduism. Operationally, these objectives are achieved in the opening up of numerous collaborations with public and religious organizations. The Hindu Union is a participant in the initiative promoted by the Municipality of Milan and the Archdiocese and offers a lesson in Hinduism as part of the history of religion project. One of the main tools supporting the integration process between religions is in fact mutual knowledge and awareness.

\section{Religious Freedom, Identity and the Universal Response to the Needs of Forced Migrants: Indications from the Construction of the Semiotic Square}

As with the first case study, an analysis of the interviews demonstrated how both groups address the relationship between religion and society, presenting a comparison between possible models of interaction and integration between the secular and religious spheres. The crucial issue of this report presents a twofold semantics detectable with the Greimas square.

The first binary opposition detected in the interview conducted with a representative of the OIDCE is seen when comparing the American and European models. For the former, religion appears as a factor serving the public debate, one able to enhance social integration. The assumption of religion as a 
constitutive component of the social dynamics visible in the public arena allows American secularism to apply a concrete form of religious freedom. On the contrary, the prevailing European approach interprets the separation between public and religious spheres in exclusivist terms, when not oppositional or alienating. The impossibility for the Church to have a voice in the public debate fosters a new European secularism based on the byword freedom from the religion.

The interview with the President of Religion for Peace in Rome notes secularism as a component of modernity, and the relationship between religion and modernity can be clearly summarized by applying the Greimas square. The golden rule proposed by the organization intends to focus on the mutual

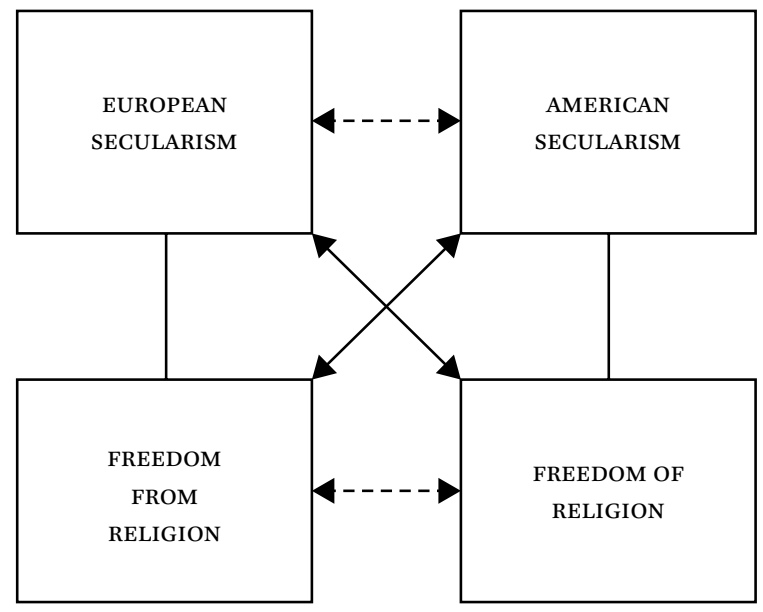

FIGURE 14.1 The Greimas square applied to interview number 1

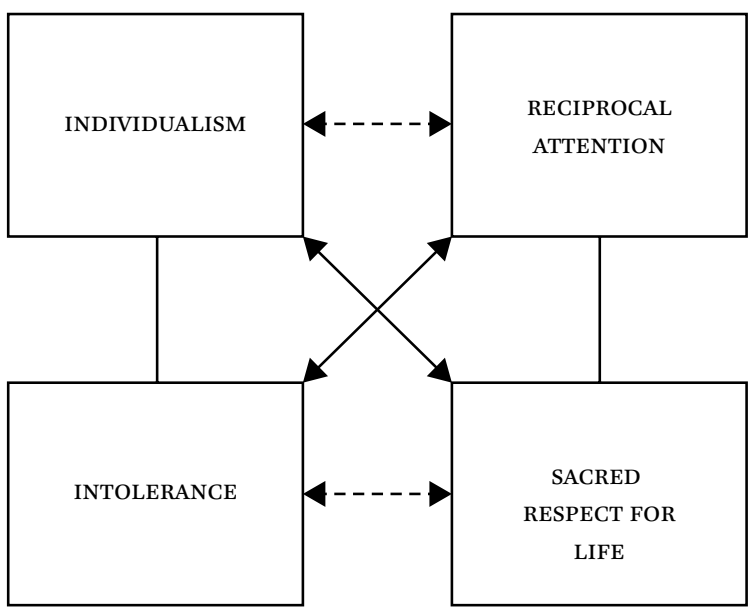

FIGURE 14.2 The Greimas square applied to interview number 2 
relationships between different religious traditions, a counter-position to the existential loneliness and the separation processes offered by modern individualistic and idealistic philosophies. Modernity has led to a general mistrust of the main human fulcrum of intolerance and mutual foreignness. In contrast, the great religious traditions agree that a point of convergence may be a sacred respect for life. By means of a growth process within religions, oriented to comparison, to a respect for diversity and the desire to locate a universalist profile, it is possible to act to prevent social tensions and conflict as well to work toward a reconciliation between the multiple identities.

A Greimas square analysis of the second case study involving the two interviews with the Sant'Egidio Community allows us to highlight how religious persecution represents the most complete manifestation of intolerance, and

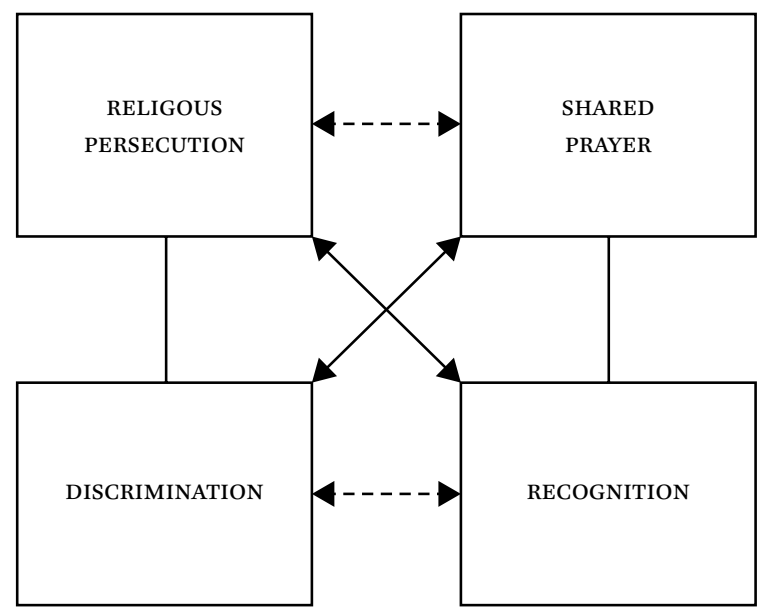

FIGURE 14.3 The Greimas square applied to interview number 6

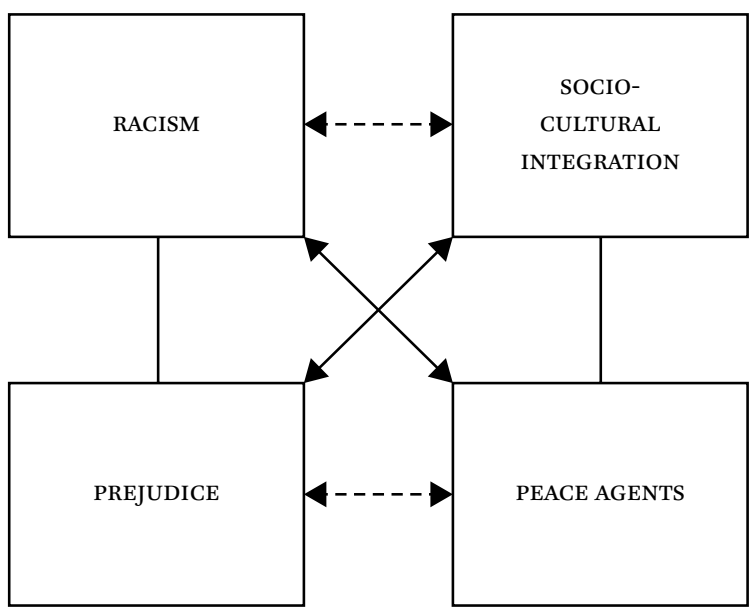

FIGURE 14.4 The Greimas square applied to interview number 3 
how this negative factor may be opposed through shared prayer, encounters based on respect for the identity of other religions.

Where religious persecution involves conflict and results in discrimination against a religious component, shared prayer addresses the diversity through a meeting and mutual recognition of the various religions.

A further application of the Greimas semiotic square to the interviews allows the definition of the opposition between racism and socio-cultural integration through two predictors, prejudice and the initiatives promoted by the Agents of Peace, which are revealed as fundamental to the actions undertaken by the organization.

The activities carried out by the migrants as Agents of Peace give and return an image of the foreigner as someone familiar to the social fabric, while attributing a positive value to the membership of the foreigner to the community. Through concrete actions, the prejudice is transformed into knowledge, a prerequisite for genuine socio-cultural integration.

The analysis continues by commenting on the third case study and the two interviews involving the Opera San Francesco for the Poor (OSF), an organization of religious inspiration. Applying Greimas square to the content proposed by the manager of the reception services makes the profound and qualifying importance of the organization of hospitality clear. This operating mode is notable in the act of acceptance, understood as the immediate passage from user registration to offer of service. The norms regarding the reception proposed by the OSF do not require the validation of the identification documents presented by users. The first contacts with the recipients are not geared exclusively to allow the use of the organization's services. There is also a willingness to accept the complete gamma of personal needs and provide the functional tools needed to meet them.

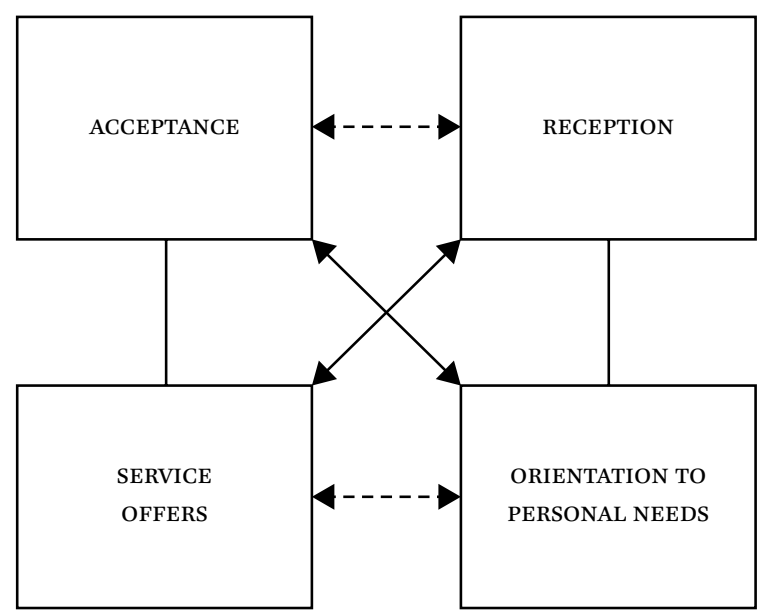

FIGURE 14.5 The Greimas square applied to interview number 4 


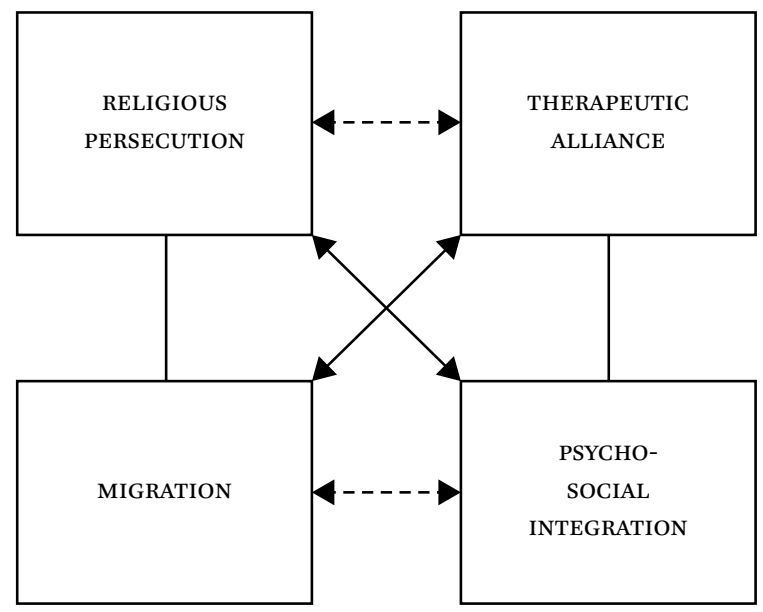

FIGURE 14.6 The Greimas square applied to interview number 8

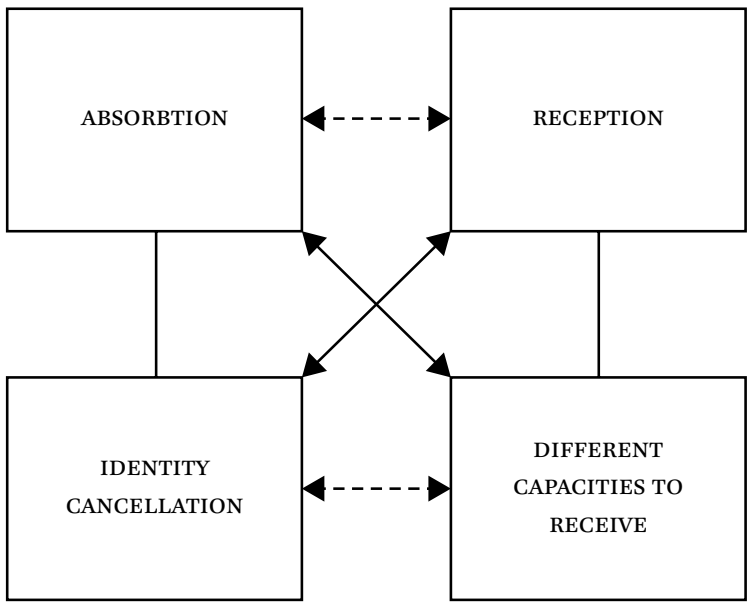

FIGURE 14.7 The Greimas square applied to interview number 5

The interview conducted with the specialist engaged in the organization's Polyclinic revealed even more clearly the personal narratives and life stories of the service users. The semantic category of religious persecution in its physical and psychological implications is very clearly outlined.

The mode of intervention, in these cases, is divided according to the transverse channels of medico-legal, legal, and psychological. The importance of the therapeutic alliance emerges at the center of the care process as a counterresponse to the traumatic experience of persecution. A timely response to the needs of the person, in its concrete and psychic expressions, makes it possible to arrive at a complete integration of the subject. 
The last analysis concerns the fundamental features of the interreligious approach promoted respectively by the Archdiocese of Milan and the Italian Hindu Union. Once more, the salient features offered by the two institutions may be understood by applying the Greimas semiotic square. The two models of interreligious dialogue, although different in what they assume, display a converging social orientation.

The Service for Ecumenism and Dialogue proposes a model involving an integration, allowing for the increase in migratory flows, of the different religious identities present in the social fabric. This is a trend in contrast to the absorption model and to an indifference in identifying differences, ${ }^{9}$ which has resulted in the failure of integration models, therefore producing a clear stigmatization of any reference to identity. The interventions promoted by the Archdiocese of Milan, in dialogue with the Municipality of Milan, aim instead at boosting a distribution model geared to reception and inclusion, one able to develop differences while respecting reciprocal identities.

The interview with the President of the Italian Hindu Union, in introducing the institution's religious training and the main features that characterize it, indicated the presence of important factors of integration inherent in the Hindu religion. Hinduism is characterized by the coexistence of a multiplicity of cultures, traditions and languages, which can lead to ethnic discrimination. However, these divisions can also act as a binding agent and an integration tool through the religion's recognition of the oneness of God. This perception of the existence of a single God and its manifestation in every person establishes

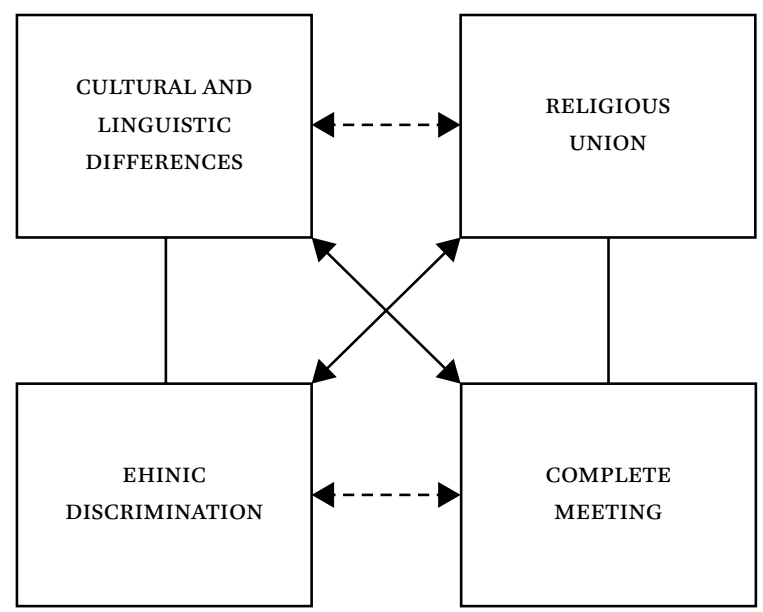

FIGURE 14.8 The Greimas square applied to interview number 7

9 See Chapter 2. 
an immediate connection with every other person, disallowing any form of conflict.

\section{Is It Possible to Reveal any Relationship between Migration and Religious Persecution in the Reception and Acceptance Practices of FBOs?}

The phenomenon of persecution for religious reasons assumes a plurality of facets in the content of the interviews, which refer in part to the mission peculiar to each organization involved in the study as well as to the different political and cultural realities of the origins of the persecution.

In the interview with the representative of the OIDCE, persecution for religious reasons is identified as a phenomenon having its geographic-political position within an Arab context in Africa and Asia, with persecution addressed mainly to the Christian faith groups. This form of persecution recurs in several European states with violence and threats against Christian refugees or asylum seekers, where it is perpetrated by other migrants. The incidence and extent of these events has led the Observatory to recognize a central theme for the future: the protection of the most vulnerable asylum seekers, namely the Christians fleeing from persecution and genocide.

Religions for Peace has detected the widespread presence of a persecution that is not defined as strictly religious, as it mainly involves minority groups that cannot be categorized according to a religious belief. The centrality of the persecution in this case moves from the religious register to the social and political one, with the identification of the presence of a significant element of difference and diversity in the group persecuted. ("It is a persecution towards religious groups as different groups, not so much for the content... because where there are these situations of extreme violence, regimes or attempts to impose regimes etc., the problem is the diversity", interview 2). In response to these situations, the organization supports those who are persecuted by maintaining stable contacts with minorities, by raising public awareness regarding situations of violence and by telling about the presence of humanitarian corridors. Examples of the groups aided are the Christian Coptic community present in the Middle East and the movement of authentic religiosity in Turkey.

Specific data about the origin of migrants because of religious persecution emerge from the interview conducted with a volunteer from the Sant'Egidio Community in Rome. These migrants are generally Christian groups from Nigeria, Egypt or Iraq, or Afghan Shiite Muslims, all minority groups in the country of origin. Religion turns out to be, just as in the case of ethnicity, a persecution factor. However, it is difficult to define the classificatory limits of 
the phenomenon. Within the context of persecution, religion and ethnicity do not exhibit features that can clearly mark a clear distinction between the two spheres ("often, it has more to do with ethnicity than religions, but here things are mixed, it is difficult to make distinctions", interview 3). In many cases, the reasons for migration remain hidden or unexpressed. In reporting the experiences of those affected by religious persecution, the volunteer stressed that to enable migrants to reveal their religious background and their experience, it is imperative that a trust relationship with the operator be established.

The Copts from Egypt show a similar form of discrimination, which interweaves economic, political and religious factors. They are discriminated for two main reasons: on the one hand, because they are followers of a minority religious community, and on the other hand because of the fact that they belong in many cases to the upper class due to their professional status (they are often the professional contact privileged by embassies or Western commercial reality) ("They suffer a double discrimination: (...)... you are a Christian and rich, that's why you are doubly discriminated", interview 6).

The manager of reception services at the Opera San Francesco noted a low percentage of people who had fled religious persecution, and the centrality of political and social component was highlighted. The religious factor is added as a contributory cause ("The migrants come from countries where there are on-going civil wars, the political and social conditions are grave. Religion is an additional factor", interview 4). However, as pointed out by the interviewee, the issue of religious persecution rarely arises during the organization's first contact with and acceptance of the migrant, emerging only after the processes of acquaintance and mutual trust are established, which is a time-consuming process. The interview conducted with a specialized operator in the same organization was able to reveal aspects of the socio-religious interrelationship and the persecution experienced in the countries of origin - and, in fact, it was the depth and intimacy of health interventions which allowed the detection of cases, not particularly numerous, of migration due to religious persecution. These cases require a dual therapeutic approach. The effectiveness of the intervention, in view of the intense suffering that the persecution experience has produced, relies on a personal and intimate integration of the patient within the social context. On the other hand, the interventions reveal the forensic documentation necessary for the acquisition of refugee status.

According to the specialist operator interviewed (interview 8), the main states of origin of migrants who have encountered social and religious persecution and who turned to the OSF Health Services are Somalia, Eritrea, China, Pakistan, Bangladesh and Sri Lanka. These migrants are, from a clinical point of view, marked by visible injuries related to torture or beatings, and invisible 
psychological wounds. The experiences of patients show that the religious factor is often inseparable from the economic and socio-political components. The existence of violent clashes between groups belonging to different ethnic groups is often the root cause of abuse towards minority groups. The religious identity is then part of the ascriptive characteristics of their communities and represents a decisive factor in the balance of power in the area.

A form of circularity between the political, ethnic, religious and social dimensions is shown, also thanks to a combination of these dimensions, which renders each one of them indistinguishable within the total of the various factors contributing to sparking the migration process. The reticular nature of these elements is confirmed in the case of Iranian women married to Italian non-Muslim men. These women cannot return to the country of origin because they would be subject to discrimination. The condition of these women is aggravated when divorced because they face an exclusion from the activities necessary for the conduct of an independent life. The example underlines once again the close connection between social, economic and religious factors.

Further geographical and social information related to persecution emerged during the interview with the Service for Ecumenism and Dialogue. In their experience, the Sub-Saharan Africa is the area where most episodes occur, and the victims are mainly female. However, the religious factor is not identified as an underlying cause of migration and arrival in Italy. The main reasons for an ebb and flow in migratory processes in these cases are economic or political. A previously unrecognized element revealed in the interview relates to the migrant conversions. Although this does not represent a specific persecution in the strict sense of the word, it is in fact retaliation against the subject and their primary relationships, particularly family.

Again, women are the main victims of such incidents.

The representative from the Italian Hindu Union provided evidence of religious persecution present in Bangladesh, where Hindus are a minority dominated by violence exercised by Muslim fundamentalists. However, the emigration in this case is once again mainly attributed to economic and social causes.

Table 14.6 summarizes the main findings from the case studies with respect to religious persecution as a migration push factor.

In conclusion, while accepting the diverse points of observation in the survey, the data that emerge from the interviews as a whole demonstrate the prevalence of a migration with a composite of causes and irreducible to a single motive. The religious factor, although present as a contributory cause, is often inseparable from the given socio-political and economic context.

The interconnection between multiplicities of factors appears as the most prevalent interpretation in the interview's texts. In fact, even in cases where it 
TABLE 14.6 Religious persecution and migration paths: a summary based on the case studies

\begin{tabular}{lllll}
$\begin{array}{l}\text { Case } \\
\text { study }\end{array}$ & FBos & Type & $\begin{array}{l}\text { Country Reason for } \\
\text { of origin migration }\end{array}$ & References \\
\hline
\end{tabular}

$\begin{array}{lllll}\text { First } & \begin{array}{l}\text { Observatory on } \\ \text { Intolerance and }\end{array} \text { tive } & \text { Asia } & \begin{array}{l}\text { Explained: } \\ \text { social political }\end{array} & \begin{array}{l}\text { Persecution is what our } \\ \text { brothers and sisters in the }\end{array} \\ \begin{array}{l}\text { Discrimination } \\ \text { against Christians }\end{array} & & \begin{array}{l}\text { Latent: } \\ \text { religious }\end{array} & \text { Arab world, Africa or Asia } \\ \text { face (FBO n. 1) }\end{array}$

\begin{tabular}{|c|c|c|c|c|}
\hline $\begin{array}{l}\text { Religions for } \\
\text { Peace }\end{array}$ & $\begin{array}{l}\text { Representa- } \\
\text { tive }\end{array}$ & $\begin{array}{l}\text { Turkey } \\
\text { Egypt }\end{array}$ & $\begin{array}{l}\text { Explained: } \\
\text { social political } \\
\text { Latent: } \\
\text { religious }\end{array}$ & $\begin{array}{l}\text { It is a persecution of } \\
\text { religious groups as } \\
\text { different groups, not so } \\
\text { much for the content ... } \\
\text { there are these extremist } \\
\text { violence situations, } \\
\text { regimes or regime } \\
\text { attempts (FBO n. } 2 \text { ) }\end{array}$ \\
\hline
\end{tabular}

Second Sant'Egidio Community (Rome)

$\begin{array}{lll}\text { Manager of } & \text { Nigeria } & \text { Explained: } \\ \text { Agents for } & \text { Egypt } & \text { ethnic } \\ \text { Peace } & \text { Iraq } & \text { religious } \\ & \text { Afghani- } & \text { economic- } \\ & \text { stan } & \text { political }\end{array}$

Often it is more of ethnicities than religions but here things are mixed, it is difficult to make distinctions. Very often, the religious factor is behind the granting of asylum. As they slowly gain courage, they tell us the reasons for the trip. At first no ... they need to trust you (FBO n. 3)

$\begin{array}{lllll}\begin{array}{l}\text { Sant'Egidio } \\ \text { Community }\end{array} & \begin{array}{l}\text { Language } \\ \text { teacher, }\end{array} & \text { China } & \text { Explained: } & \text { It's a difficult subject. } \\ \text { (Milan) } & \text { volunteer } & & \text { parties } & \text { Perhaps they don't want } \\ & & \text { political } & \text { to tell you, perhaps it is } \\ & & \text { Latent: } & \text { intertwined with other } \\ & \text { religious } & \text { migration factors... Many } \\ & & \text { tell us about the political } \\ & & \text { problems, many others }\end{array}$




\begin{tabular}{lllll}
$\begin{array}{l}\text { Case } \\
\text { study }\end{array}$ & FBos & Type & $\begin{array}{l}\text { Country Reason for } \\
\text { of origin migration }\end{array}$ & References \\
\hline
\end{tabular}

talk about the economic issues... but they don't talk about these things (religious persecution) with a Christian woman (FBO n. 4)

Third Church

Specialized Somalia, Explained: operator Eritrea China, political Pakistan
For religious persecution there are the signs... invisible wounds and more visible ones related to the persecution of Christians, Muslims ... because they are not of the same religion or of a lower caste. Because even there the social and religious system breaks down (FBO n. 5)

Reception service aide
Explained: political social Latent: religious
It is very unlikely that such a difficult and internalized subject emerges... The migrants come from countries where there are on-going civil wars, the political and social conditions are grave. Religion is an additional factor (FBO n. 6) 
TABLE 14.6 Religious persecution and migration paths: a summary based on the case studies (cont.)

\begin{tabular}{|c|c|c|c|c|c|}
\hline $\begin{array}{l}\text { Case } \\
\text { study }\end{array}$ & FBOS & Type & $\begin{array}{l}\text { Country } \\
\text { of origin }\end{array}$ & $\begin{array}{l}\text { Reason for } \\
\text { migration }\end{array}$ & References \\
\hline \multirow[t]{2}{*}{ Fourth } & $\begin{array}{l}\text { Ecumenism and } \\
\text { Dialogue Service, } \\
\text { Archdiocese of } \\
\text { Milan }\end{array}$ & Manager & $\begin{array}{l}\text { Sub- } \\
\text { Saharan } \\
\text { Africa } \\
\text { Nigeria }\end{array}$ & $\begin{array}{l}\text { Explained: } \\
\text { political } \\
\text { parties } \\
\text { Latent: } \\
\text { religious }\end{array}$ & $\begin{array}{l}\text { For whoever does not } \\
\text { want to convert, to travel, } \\
\text { a trip that may be one } \\
\text { towards death is the only } \\
\text { possible choice. However, } \\
\text { not a large number of } \\
\text { people affected by } \\
\text { discrimination arrive in } \\
\text { Italy. There are other } \\
\text { causes: economic, politics, } \\
\text { or sometimes there is a } \\
\text { combination of factors } \\
\text { (FBO n. } 7 \text { ) }\end{array}$ \\
\hline & $\begin{array}{l}\text { Italian Hindu } \\
\text { Union-Milan } \\
\text { Section }\end{array}$ & Manager & $\begin{array}{l}\text { Bangla- } \\
\text { desh }\end{array}$ & $\begin{array}{l}\text { Explained: } \\
\text { economic } \\
\text { Latent: } \\
\text { religious }\end{array}$ & $\begin{array}{l}\text { There was a gentleman in } \\
\text { tears, desperate, saying } \\
\text { that they returned a } \\
\text { relative one piece at a time } \\
\text {... these are frightening } \\
\text { things, things that we } \\
\text { know nothing of ... But I } \\
\text { wouldn't say that there is } \\
\text { a strong migrant flow } \\
\text { towards Italy for persecu- } \\
\text { tion reasons. The } \\
\text { migration is more } \\
\text { economic in origin (F Bо } \\
\text { n. } 8 \text { ) }\end{array}$ \\
\hline
\end{tabular}


is themed as the direct or manifest reason for the choice to migrate, religion never occurs as an isolated element but is always combined with socio-political and economic factors. This constant feature underlines above all the differences in the context in which persecution takes place and that of the culture of the host countries. The conceptual categories allowing a clear distinction between the religious sphere and the social, political and economic one in the Western context help to ensure freedom from any religiously motivated persecution. As noted by the representative from the Observatory for Intolerance and Discrimination against Christians in Europe, it is not possible to speak of persecution in the European context. Although there are episodes of discrimination and intolerance, the substantial characteristics of persecutory actions do not find expression. The public affirmation of violence and the denial of any right of any citizen on the basis of religious affiliation are in complete opposition to the principles of law and secularism on which coexistence and social order in Europe are based and stabilized. This framework, both conceptual and practical, allows to understand the difficulties encountered in defining the identity of a religious factor that manifests itself in the migrant population according to codes that are not only religious, but also political, social and economic. As a result, the cross-factor, which occurs in all the analyzed interviews, is given by the mixture between the religious, political, social and economic, and only a small number of cases clearly present religion as a distinctive and qualifying factor in migration. Narratives that did qualitatively designate religion as a manifest cause of migration were recorded in interviews conducted with the manager of the Peace Agent movement of the Community of Sant'Egidio in Rome and the specialist operator of the Opera San Francesco. In each case, a single migrant person was referred to. By resorting to the previously described AGIL scheme, it emerges that the operating code of both services is defined in terms of an interpersonal relationship (A) regulated by temporal continuity (I), characterized by attention/care for the other $(\mathrm{L})$, encouraging trust $(\mathrm{G})$ :

trust is needed $(\mathrm{G})$... also through a fundamental key, the personal relationship between the operator and the migrant (A), the possibility to express oneself is created (L). The recipient always has one or two aid personnel in the organization as a point of reference. Time is required, sometimes even years $(\mathrm{I})$. (interview 3 )

We have to work with the person (L) ... at first we worked on practical things, the concrete needs, "how do you feel" (A), an alliance first, then the therapy, then we pursue the person's needs (I) ... perhaps trust follows (G). (interview 8) 


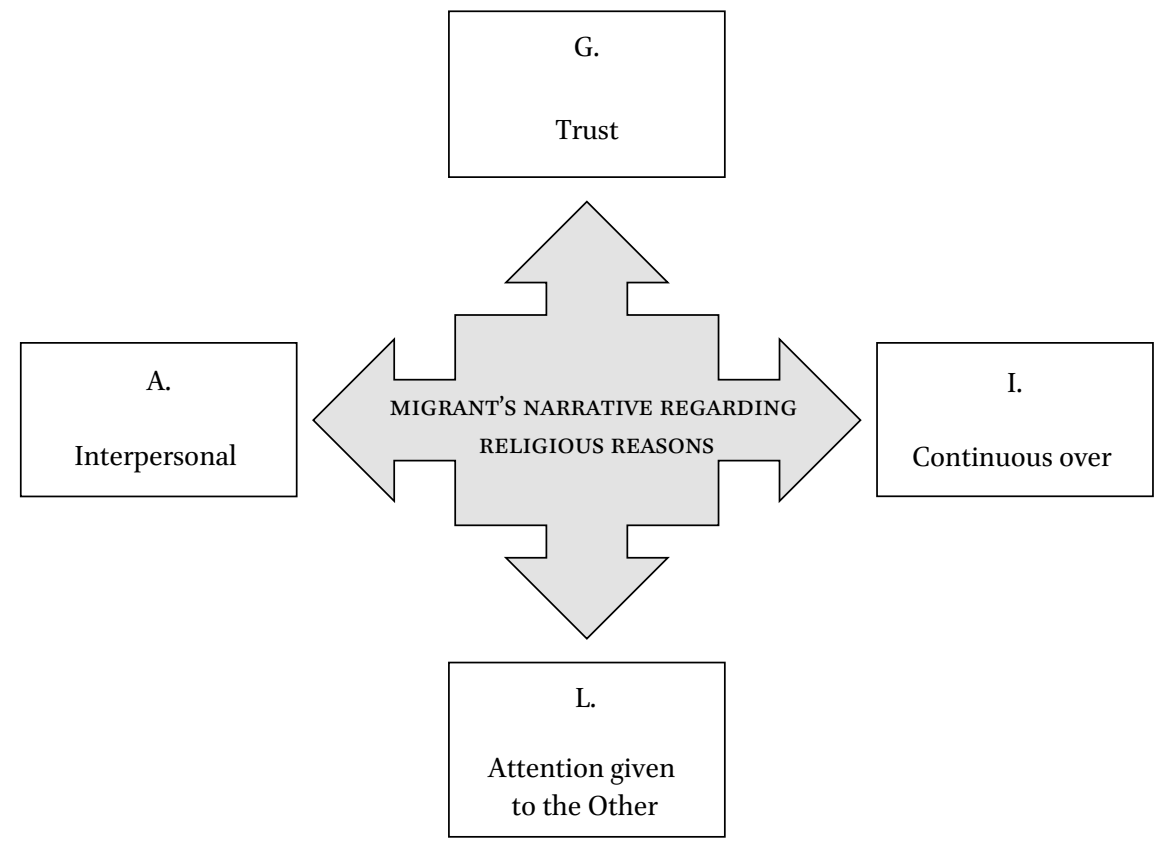

FIGURE 14.9 Migratory processes and the religious dimension in migrant narratives

The application of AGIL (Adaptation, Goal attainment, Integration, Latent pattern maintenance) in the interpretation of the content allows an observation of the constituent categories of the narratives where religion is detected as the manifest cause of the migration process. The media (A) indicate the opening to a deep dialogue with the migrants, the interpersonal and direct relationship. This contact follows the historical path of sharing and mutual growth between subjects, and it is dependent on (I), the temporal continuity of the exchange between the subjects. The value $(\mathrm{L})$, which supports the relational structure, is represented by the person-centered attention and the care demonstrated towards the other. Finally, the precise purpose $(G)$ is the establishment of a trust relationship with the migrant (Figure 14.9).

The time variable in relational continuity is therefore crucial in detecting the emergence of religious data and for the accounting of experiences and stories articulated on several levels.

The reading of this specific relational structure, able to identify the underlying causes of migration in relation to religious identity, makes the definition of those contextual aspects possible, thus allowing the transmission of intercultural motivations - a definition that would otherwise remain submerged. The analysis of the complete body of the interviews highlighted the difficulty the 
interviewees have in delimiting the field of religion due to the clear discrepancies between their own pragmatic and conceptual references and those projected by migrants. The texts highlighting religion as the direct cause of migration choice do not deny the plurality of factors involved but, at the same time, they recognize the particular gravity of the religious factor. This recognition identifies a twofold process of opening between the migrant and the operator. On the one hand, the migrants manifest their experience as a result of the establishment of a personal and trusting relationship with the operator. On the other hand, the operator involved in the same relationship learns of the other's reality and understands it more and more. The reciprocity of what is understood as an exchange generates trust towards the host context and at the same time a familiarity of foreigners.

Pursuing the Common Good through Interreligious Dialogue: a "Good Practice" Instituted by ғво s

Although religion as a motive for migration is scarcely supported by the direct statements in the texts, its interpretation as a defining element of the integration process between different confessional traditions is demonstrated not only transversally throughout the interviews; it also assumes its own specific connotation and articulation. The semiotic squares identified for each case study, in denoting the profound significance of narratives, capture the focus of the interviews in the interweaving of different religious identities and their social recognition. Table 14.7 specifies the values and actions characterizing the interreligious dialogue and those relating to religious integration.

The texts that make up the first case study recognize religion as a constitutive element of human beings and of social life. Both organizations have a critical attitude towards European secularism and the individualistic and idealistic profile prevalent in modernity. The two interviews paint a highly complementary picture regarding the position of religion within the social context. The Observatory on Intolerance and Discrimination against Christians in Europe aims to protect religious freedom within the European context through the observation of the dialogue with public institutions, whereas the Religion for Peace proposes new growth areas for religion through an open dialogue and an exchange of ideas with the different traditions.

The identification of a public space for association memberships highlighted in the first paragraph of this chapter is sometimes problematic, as seen clearly by the OIDCE protection of religious presence in the public sphere. Potential risk factors include the possible exclusion of the organization from the 
TABLE 14.7 Values and actions in the interreligious dialogue and religious integration

\begin{tabular}{lll}
\hline Case FBOs & Interreligious dialogue Religious integration \\
studies &
\end{tabular}

\begin{tabular}{|c|c|c|c|c|c|}
\hline & & Values & Actions & Values & Actions \\
\hline \multirow[t]{2}{*}{ First } & $O I D C$ & & & $\begin{array}{l}\text { Freedom of } \\
\text { religion }\end{array}$ & $\begin{array}{l}\text { Transmission } \\
\text { of informa- } \\
\text { tion and data }\end{array}$ \\
\hline & Religions for Peace & $\begin{array}{l}\text { Sacred } \\
\text { respect of } \\
\text { life }\end{array}$ & $\begin{array}{l}\text { Dissemina- } \\
\text { tion, training } \\
\text { and meetings } \\
\text { between } \\
\text { religious } \\
\text { communities }\end{array}$ & & \\
\hline \multirow[t]{3}{*}{ Second } & Sant'Egidio & & & Socio- & Peace Agents \\
\hline & Community (Rome) & & & $\begin{array}{l}\text { cultural } \\
\text { integration }\end{array}$ & \\
\hline & $\begin{array}{l}\text { Sant'Egidio } \\
\text { Community (Milan) }\end{array}$ & Recognition & $\begin{array}{l}\text { Shared } \\
\text { prayer } \\
\text { periods }\end{array}$ & & \\
\hline Third & $\begin{array}{l}\text { Opera San } \\
\text { Francesco }\end{array}$ & $\begin{array}{l}\text { Dignity of } \\
\text { the person }\end{array}$ & Hospitality & $\begin{array}{l}\text { Promotion } \\
\text { of human } \\
\text { dignity }\end{array}$ & $\begin{array}{l}\text { Therapeutic } \\
\text { alliance }\end{array}$ \\
\hline \multirow[t]{2}{*}{ Fourth } & $\begin{array}{l}\text { Service for Ecumen- } \\
\text { ism and Dialogue }\end{array}$ & $\begin{array}{l}\text { Ability to } \\
\text { accept } \\
\text { differences }\end{array}$ & Ecumenism & & \\
\hline & Italian Hindu Union & & & $\begin{array}{l}\text { Complete } \\
\text { union with } \\
\text { each other }\end{array}$ & Training \\
\hline
\end{tabular}

SOURCE: AUTHORS' PERSONAL ELABORATION

social context, and the emerging of social aspects of intolerance and discrimination unfavorable to the co-construction of common public spaces.

Important and parallel to these difficulties are the experiences in which religion assumes a specific social function, that of peace and of understanding of 
social complexity, such as in the case of Religions for Peace. By means of dialogue and a mutual recognition of the various denominations, religion becomes the form through which a common sacred respect for life is asserted, a respect shared by all the great traditions, as well as by the principle eliciting a common concern for the particularities of the other. The place occupied by religion in the public sphere is therefore crucial in confronting major global crises.

The creation, maintenance and promotion of public spaces for the religious dimension does not produce situations that, once acquired, remain stable. The spaces require continuous attention, defense, as in the OIDCE action, and promotion, such as that undertaken by Religions for Peace.

The second case study addresses the issue of religion by following a trajectory in part superimposed on the reading of the preceding case study. It can on the one hand be identified in the founding value of the Sant'Egidio Community and its services ("For Sant'Egidio, service is the concrete expression of what our faith is ... you are a Christian, you're a believer when you recognize Christ in the poor", interview 6). On the other hand, the policy of dialogue and respect for all religious traditions pursued by the organization helps to establish greater social integration, avoid conflict, alleviate mistrust and improve the social climate.

Religion is therefore the point of origin for the Community's activities, and the point of arrival in the implementation of a relationship between the different religious beliefs. Interreligious dialogue is presented as an important step in reaching an understanding of the social context ("We pray alongside each other, each according to their faith ... taking advantage of the time of prayer as a spiritual nourishment in order to develop a vision of dialogue which in our view is the only one that makes sense when you are faced with the great tragedies of the world") and a mutual recognition of identity.

The religiosity proposed by the Community is not geared to proselytism and does not preclude access to operators or users of different faith. It establishes a direction towards shared values based on solidarity, hospitality, peace and sharing. In this sense, the Community "constructs" an open space for multiple identities, which, however, orient towards each other by adopting the same symbolic code.

The issue of identification of a public space for religion is in this case subject to the placement of the religious identity, or rather, the religious identities, at the meso level. This placement is adequately symbolized by the work of the Peace Agent movement, where the free services received by the recipients is returned to the social context through services performed in aid of others in fragile conditions. This interchange establishes a double and nondenominational bond between the religious values proposed by the body and the migrant integration process. The integration is carried out through the opening up of an interreligious dialogue, which brings the faithful of the 
different communities together. In addition, the foundations and services offered by the Community contribute to the integration of foreigners into society.

The religious dimension in the third study is present by inference and is not made obvious by a direct relationship between religion and the services offered by the organization. Instead, the identification of a public space for the religious dimension is latent, perceived rather through the articulated range of interventions achieved.

The Opera San Francesco is a Franciscan religious institution. Its many services and aids offered to a mainly foreign recipient group belonging to a variety of religious confessions contribute to the creation of a public space located within the folds of the broad range of operative units characterizing this ғвоs. These spaces at once public and internal may generate an interreligious dialogue between the operator and the migrant, which can in turn lead to existential paths of social integration. The presence of consecrated personnel and religious symbols is not imposed as a qualifying element of the services offered. The choice to professionalize the services and make them available to foreigners has influenced the establishment of an environment devoid of religious connotations. The religious element is reflected, however, in the mode of implementation of the interventions, in particular in clinical activities where the required personal exchange with the patient inevitably opens an interreligious and intercultural dialogue ("You have to enter the culture ... then you realize that you have to keep a distance. With the presence of the mediator we can help ... very quickly it is we who become the stranger", interview 8).

The last case study allows us at this point to address the issue of religion in more detail by examining the theme of dialogue between the different faiths and the relationship between religion and social integration. The point of observation of the religious phenomenon in this study assumes a different perspective. The interview conducted with the manager of the Service for Ecumenism in Milan demonstrated existing opportunities to establish a dialogue with other religious traditions, contributing to the integration of these communities within the social fabric. The aims of the service reside in the research and development of interreligious dialogue, which results in a practical sense in a direct relationship with the faithful of other religions. To this end, a model is proposed of public space geared to the reception of migrants and respect for different cultural and religious identities.

What emerges from the interview conducted with the representative of the Italian Hindu Union, however, is a more direct correlation between the religious dimension and the social integration process, which establishes porous borders between the two spheres. The element qualifying integration is in fact 
identified in the recognition of a divinity in the other ("I see God in you ... so it is nothing other than you yourself, so therefore this relationship means that if you really see the other as such you cannot be violent, you cannot do anything to the other person, because it would mean harming yourself, you would be harming God himself", interview 7). The relationship with the different religious traditions is marked by the same identification process ("We all believe in the same reality ... if we are asked "Do you believe in God?" we answer "(We believe in the God) in which you also believe", interview 7). Such mingling, while not infringing on the boundaries of the secular state, is demonstrated through a lifestyle, one intrinsically oriented towards both religious and social integration. The public space for the religious dimension in the Union seems better constructed at the micro level in relations between the members of different religions and less at the State/institutional level ("Hinduism has the concept of integration in its DNA, we do not discriminate against other religions, we see God in everything. It has its natural vocation to participation", interview 7 ).

The Hindu religious process of identification of faiths and of all life does not preclude other forms of interreligious dialogue present among the activities promoted by the body.

While conceptualizing the mutual relationship between the various confessional traditions from different points of departure, both organizations agree on the importance of religion as a social glue and as an integration factor in the presence of multiple cultural, ethnic and national identities. They also both recognize the possibility of creating a more complete integration of foreigners, which accepts the specific differences of identity within the social context. The dialogue between religious communities supported by the Service for Ecumenism is a first step in creating an atmosphere of respect for differences in identity and a recognition of the gains this exchange brings both in the formation of an integrated religious knowledge of different confessional traditions and by contributing to the coexistence of different communities within the same religious or social context. The teaching of the history of religion in schools, undertaken by the organization, is supported by representatives of all religions and contributes to the formation of a conscious understanding of diversity and its positive aspects. At the same time, the sharing of worship spaces between religious communities, as well as the establishment of new religious communities within the broader social context, promotes a mutual understanding and acceptance process.

Basing on their recognition of one God and the divinity that unites all human beings and living organisms, the Italian Hindu Union incorporates the integration of religious and social differences within their religious orientation. 
They represent two implementation forms of this combination: the sociocultural reality of India and the adaptability of Hindu migrants. India is a State deeply divided socially and politically and marked by strong internal ethnic discrimination. The binding element making social integration possible is contained in the common religion and the sharing of places of worship. The Hindu migrants tend, however, to express their faith within the context in which they live through participation and integration into society ("There are 20,000 people in the Hindu community ... in Lombardy. But they are not such an obvious presence because they are inserted into society, they work ... they are therefore a very integrated group of people", interview 7).

The theme of a common good pursued through specific activities and practices based on the recognition of the religious dimension as an inalienable right emerges clearly in both organizational practices.

This trait is the red thread connecting the actions of the Fвоs considered. Through specific actions of voice and loyalty (Hirschman, 1970), via interventions linked to the initial reception of persons forced to migrate, through the provision of medium and long term services intended to achieve an acceptable quality of life, and the implementation of educational and cultural services, the organizations contribute to the realization of a common articulated good in which the religious dimension is not expunged but rather contributes to the building up of specific public spaces.

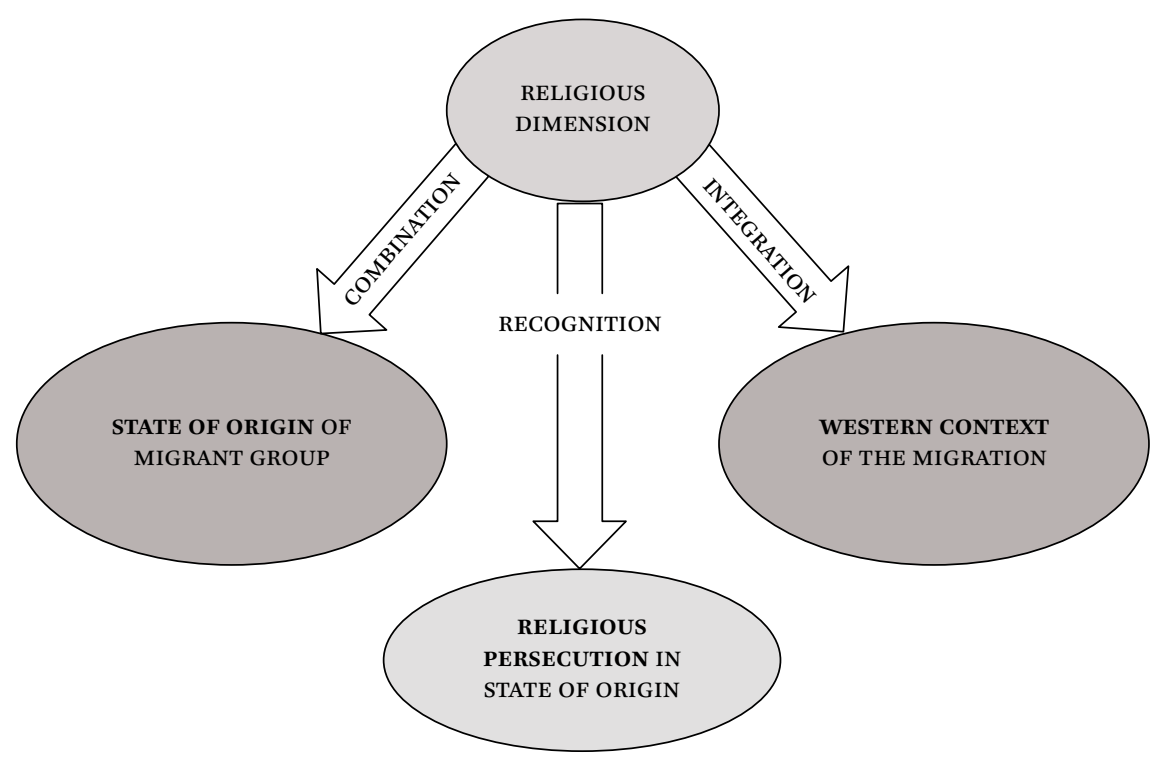

FIGURE 14.10 Action conducted by the FBOs and the explication of the religious dimension 
Overall, from the qualitative investigation conducted and the interpretation of the relationship between the religious dimension and action taken of ғво from a meta-reflexive perspective, three articulations of the religious factor emerge. The first focuses on the singular and unique blends of religious, political and social spheres present in the countries of origin. The second is related to migratory cases linked to religious persecution, and the last is the extension of the relationship between religion and social integration in the Western context represented by the organizations.

Religious identity is thus defined in relation to the culture of the migrant population as an element inseparable from the broader social, political, ethnic and economic contexts. The organizations are active promoters of a social integration mode, which sees the religious dimension as an important reception tool as well as a connecting factor for intercultural dialogue, a clear contributor to the creation of specific public spaces. A very particular approach is useful in allowing experiences of religious persecution to be revealed. Close contact with the migrant and the establishment over time of a lasting and stable interpersonal relationship characterized by attention and care on the part of the operator may lead the migrants to trust the operators enough to be able to express themselves. The operators, on their part, gain a closer familiarity with the cultural and symbolic codes of the migrant.

The triple articulation of the religious dimension described above (see Figure 14.10) allows the emergence of a relational semantic in the meeting of the different cultures and religious traditions (Donati, 2008). The recognition of the Other and their identity is the point of departure for the description of the religious matrix borne by the migrants. Similarly, the establishment of a relationship of reciprocity between different identities enables integration of the differences in the context of hospitality (Zanfrini, 2019). This integration recognizes the real otherness between the subjects, one rooted in an authentic symbolic and instrumental sharing. "The sharing is not between two reflections (two similar entities mirroring each other) but between two unique entities which, while retaining their impenetrability without losses (because they continue to live their memberships in other social and cultural worlds), reveal themselves as different in reference to a reality they have in common, for example, the human race" (Donati, 2008: 84). Finally, the reflexivity, which allows the detection of those very intimate cases of suffering and discomfort, caused by episodes of religious persecution, gives body to a morphogenetic relational form, one that evolves gradually through the establishment of a relationship of trust and familiarity between ego and alter. 